\title{
Analisis Perbandingan Tiga Metode Untuk Mendiagnosa Penyakit Mata Pada Manusia
}

\author{
Ahmad Fahmi Adam* ${ }^{1}$, Iskandar Fitri ${ }^{2}$, Novi Dian Nathasia ${ }^{3}$ \\ ${ }^{1}$ Program Studi Sistem Informasi, ${ }^{2,3}$ Program Studi Informatika \\ Fakultas Teknologi Komunikasi dan Informatika Universitas Nasional, Jakarta \\ email : ${ }^{* 1}$ adamahmadfahmi@gmail.com, ${ }^{2}$ iskandar.fitri@civitas.unas.ac.id, ${ }^{3}$ novidian@civitas.ac.id

\begin{abstract}
Abstrak
Untuk mendiagnosa penyakit mata pada manusia diperlukan perhitungan probabilitas yang terbaik. Karena mata merupakan salah satu bagian terpenting pada tubuh manusia yang harus di jaga kesehatannya. Penelitian ini bertujuan untuk menganalisis perbandingan dari 3 metode diantaranya : metode Case-Based Reasoning, Nä̈ve Bayes dan Certainty Factor sehingga bisa diketahui metode mana yang terbaik untuk melakukan pendiagnosaan. Setelah melakukan perbandingan, untuk perhitungan metode Case-Based Reasoning didapatkan hasil probabilitas 61,6 \%, metode Nä̈ve Bayes didapatkan hasil 56,36\% dan metode Certainty Factor didapatkan hasil 90,4\%. Dapat disimpulkan, metode Certainty Factor adalah metode yang terbaik untuk melakukan pendiagnosaan penyakit mata pada manusia. Setelah itu, akan dibuatkan suatu sistem pakar menggunakan metode Certainty Factor untuk mendiagnosa penyakit mata pada manusia. Sistem pakar merupakan peniru suatu pakar dalam melakukan diagnosis suatu penyakit. Tujuan dibuatkan sistem pakar ini, supaya dapat membantu pasien untuk mendiagnosa jenis penyakit mata apa berdasarkan gejala gejala yang dialaminya.
\end{abstract}

Kata kunci: case-based reasoning, certainty factor, diagnose, naïve bayes, penyakit mata, sistem pakar.

\begin{abstract}
To diagnose eye disease in humans, it is necessary to calculate the best probability. Because the eyes are one of the most important parts of the human body that must be kept healthy. This study aims to analyze the comparison of 3 methods including: Case-Based Reasoning, Nä̈ve Bayes and Certainty Factor methods so that it can be known which method is the best for diagnosing. After doing a comparison, for the calculation of the Case-Based Reasoning method, the probability result is $61.6 \%$, the Naïve Bayes method is $56.36 \%$ and the Certainty Factor method is $90.4 \%$. It can be concluded that the Certainty Factor method is the best method for diagnosing eye diseases in humans. After that, an expert system will be made using the Certainty Factor method to diagnose eye diseases in humans. An expert system is an imitation of an expert in diagnosing a disease. The purpose of this expert system is to help patients to diagnose what type of eye disease based on the symptoms they experience.
\end{abstract}

Keywords: case-based reasoning, certainty factor, diagnosis, naïve bayes, eye disease, expert system.

\section{PENDAHULUAN}

Disaat ini dunia teknologi berkembang pesat sangat menopang seluruh segi kehidupan di masyarakat dalam pertumbuhan zaman serta kehidupan, dalam perihal kesehatan merubah perihal manual jadi suatu sistem berbasis teknologi sangat lah berarti sebab perihal ini dapat menolong para lembaga kesehatan khususnya dalam memperbaharui informasi ataupun 
memudahkan akses layanan kepada masyarakat. Semacam halnya disaat ini merupakan permasalahan dalam riset tentang sistem informasi mengenai indikasi penyakit mata [1].

Salah satu anggota badan yang sangat vital pada manusia adalah mata, mata ialah salah satu bagian tubuh yang sangat dilindungi kesehatannya. Mata yang kurang sehat hendak memberikan akibat kurang baik untuk si pengidap sebab bisa mengganggu proses kegiatan dari si pengidap [2]. Dengan mata melihat, manusia bisa menikmati keindahan alam serta berinteraksi dengan area sekitar dengan baik. Bila mata mengalami kendala ataupun penyakit mata, hingga akan berdampak sangat parah untuk kehidupan manusia. Jadi sudah mestinya mata ialah anggota badan yang butuh dilindungi dalam kesehatan sehari- hari [3].

Sebab mata ialah bagian terpenting pada tubuh manusia, jadi tidak sembarang untuk memutuskan indikasi penyakit mata apa yang dialami oleh penderita. Maka dalam penelitian ini akan melakukan analasis perhitungan probabilitas perbandingan 3 metode adalah: Case- Based Reasoning, Naïve Bayes dan Certainty Factor. Setelah itu akan diambil salah satu metode terbaik yang akan digunakan untuk dibuatkan sistem pakar. Sistem pakar adalah sistem berbasis komputer yang memanfaatkan pengetahuan, kenyataan serta metode penalaran dalam membongkar kasus yang umumnya cuma dapat dipecahkan oleh seorang pakar dalam bidang tertentu [4].

Dengan adanya sistem pakar ini nantinya bisa dijadikan layanan konsultasi untuk menunjang dalam mendiagnosa tipe penyakit mata pada penderita bersumber pada gejala- gejala klinis yang terjadi pada penderita, sehingga bisa digunakan dalam pengambilan kesimpulan diagnosa awal saat sebelum melaksanakan pengecekan intensif laboratorium.

\section{METODOLOGI PENELITIAN}

Penelitian ini bertujuan untuk mengetahui metode mana yang paling tepat dan terbaik untuk mendiganosa penyakit mata pada manusia, metode yang di analisis diantara nya, yaitu : Case Based Reasoning (CBR), Naïve Bayes dan Certainty Factor. Setelah mengetahui metode apa yang terbaik dan tepat maka akan di buat kan suatu sistem pakar. Untuk mencapai tujuan tersebut maka langkah-langkah yang dilakukan adalah sebagai berikut:

\subsection{Analisis Permasalahan}

Dalam membangun suatu sistem yang dapat mengadopsi proses serta metode memasukkan pengetahuan dari seorang pakar ke dalam komputer sehingga bisa membagikan kemudahan dalam mendiagnosa penyakit mata pada manusia dengan kualitas pakar, hingga diperlukan pengolahan basis pengetahuan kepakaran dari seorang pakar yang dibangun ke dalam aturanaturan serta fakta- fakta yang bisa menghasilkan diagnosa serta kesimpulan cocok dengan kaidah- kaidah basis pengetahuan yang ada. Berikut ini ialah pembuatan aturan- aturan yang berasal dari pengetahuan pakar [5].

Tabel 1. Data Kepakaran Penyakit Mata pada Manusia

\begin{tabular}{|c|l|c|c|c|}
\hline \multirow{2}{*}{ No } & \multicolumn{2}{|c|}{ Daftar Gejala } & \multicolumn{3}{|c|}{ Data Penyakit Mata Pada Manusia } \\
\cline { 3 - 5 } & & Konjungtivitis & Katarak & Glaukoma \\
\hline 1 & Iritasi & 0,6 & & \\
\hline 2 & Infeksi & 0,6 & & \\
\hline 3 & Pandangan kabur & 0,4 & 0,6 & \\
\hline 4 & Mata terasa nyeri & 0,6 & & \\
\hline 5 & Peka terhadap cahaya & 0,2 & & \\
\hline 6 & Bulu mata sering jatuh & 0,2 & & \\
\hline 7 & Ketajaman penglihatan & & 0,6 & \\
\hline
\end{tabular}




\begin{tabular}{|c|c|c|c|}
\hline & berkurang & & \\
\hline 8 & Sensitivitas & 0,6 & \\
\hline 9 & Kontras & 0,4 & \\
\hline 10 & $\begin{array}{l}\text { Bayangan dan visi kurang } \\
\text { jelas }\end{array}$ & 0,6 & \\
\hline 11 & $\begin{array}{l}\text { Bila memandang lampu } \\
\text { maka akan timbul warna } \\
\text { pelangi }\end{array}$ & & 0,4 \\
\hline 12 & $\begin{array}{l}\text { Mata terasa sakit sebab } \\
\text { posisi mata dalam kondisi } \\
\text { bengkak }\end{array}$ & & 0,4 \\
\hline 13 & $\begin{array}{l}\text { Rasa ingin mengedip terus } \\
\text { menerus dengan menekan } \\
\text { kedipan berlebihan }\end{array}$ & & 0,2 \\
\hline
\end{tabular}

Berdasarkan data kepakaran penyakit mata pada manusia pada tabel 1, dapat dibentuk basis aturan (rule), Adapun daftar aturan (rule) yang dibentuk adalah sebagai berikut:

Rule 1: $\quad I F$ iritasi $=$ Yes $A N D$ infeksi $=$ Yes $A N D$ pandangan kabur $=$ YES $A N D$ mata terasa nyeri $=$ Yes $A N D$ peka terhadap cahaya $=$ Yes $A N D$ bulu mata sering jatuh $=$ Yes THEN Penyakit $=$ Konjungtivitis

Rule 2: IF pandangan kabur $=$ Yes $A N D$ ketajaman penglihatan berkurang $=$ Yes $A N D$ sensitivitas $=$ Yes $A N D$ kontras $=$ Yes $A N D$ bayangan dan visi kurang jelas $=$ Yes THEN Penyakit $=$ Katarak

Rule 3 : IF bila memandang lampu maka akan timbul warna Pelangi $=$ Yes $A N D$ mata terasa sakit sebab posisi mata dalam kondisi bengkak = Yes $A N D$ rasa ingin mengedip terus menerus dengan menekan kedipan berlebihan $=$ Yes THEN Penyakit $=$ Glaukoma

\subsection{Analisis Perhitungan Metode Case Based Reasoning}

Case-Based Reasoning( CBR) menggambarkan sistem penalaran yang memanfaatkan pengetahuan lama untuk menuntaskan kasus baru. Penyajian pengetahuan (knowledge representation) terbuat dalam wujud kasus- kasus (cases) [6]. Yang jadi basis pengetahuan pada case- based reasoning merupakan kenyataan berbentuk kasus- kasus sebelumnya yang pernah ada dan serangkaian alur untuk mengecek, menghitung, dan merumuskan sesuatu dari kasus yang diberikan [7].

$$
\operatorname{Similarity}(\mathrm{T}, \mathrm{S})=\frac{\left(\mathrm{S}_{1} * \mathrm{~W}_{1}\right)+\left(\mathrm{S}_{2} * \mathrm{~W}_{2}\right)+\cdots \ldots+\left(\mathrm{S}_{n} * \mathrm{~W}_{n}\right)}{\mathrm{W}_{1}+\mathrm{W}_{2}+\ldots \ldots+\mathrm{W}_{\mathrm{n}}}
$$

Seorang pasien menderita gejala-gejala : iritasi, pandangan kabur dan mata terasa nyeri 1. Menelusuri runut maju terhadap rule-rule yang ada

Rule 1: $\quad I F$ iritasi $=$ Yes $A N D$ pandangan kabur $=$ Yes $A N D$ mata terasa nyeri $=$ Yes $T H E N$ Penyakit $=$ Konjungtivitis.

Rule 2: IF pandangan kabur $=$ Yes THEN Penyakit $=$ Katarak.

Berdasarkan hasil dari proses penelusuran dengan menggunakan Teknik infersi Forward Chaining, diketahui bahwa pasien tersebut menderita penyakit mata : Konjungtivitis dan Katarak.

2. Melakukan proses perhitungan dengan metode Case Based Reasoning sesuai dengan persamaan rumus (2-1) dan identifikasi nilai kepastian gejala didapat dari tabel 1 :

a. Jenis penyakit Konjungtivitis:

Iritasi, pandangan kabur dan mata terasa nyeri 
Similarity $(\mathrm{X}, \mathrm{P} 1)=\frac{(1 * 0,6)+(0,0,6)+(1 * 0,4)+(1 * 0,6)+(0 * 0,2)+(0 * 0,2)}{0,6+0,6+0,4+0,6+0,2+0,2}$

$$
\begin{aligned}
& =\frac{0,6+0,4+0,6}{2,6} \\
& =\frac{1,6}{2,6} \\
& =0,6154 \text { (Hasil CBR) }
\end{aligned}
$$

Maka hasil perhitungan dengan metode Case Based Reasoning untuk penyakit Konjungtivitis adalah 0,6154 atau $61,54 \%$

b. Jenis penyakit Katarak:

Pandangan kabur

$$
\begin{aligned}
\text { Similarity }(\mathrm{X}, \mathrm{P} 2) & =\frac{(1 * 0,6)+(0 * 0,6)+(0 * 0,6)+(0 * 0,4)+(0 * 0,6)}{0,6+0,6+0,6+0,4+0,6} \\
& =\frac{0,6}{2,8} \\
& =0,2143(\text { Hasil CBR) }
\end{aligned}
$$

Maka hasil perhitungan dengan metode Case Based Reasoning untuk penyakit Katarak adalah 0,2143 atau 21,43\%

3. Kesimpulan Perhitungan

Nilai Max (Konjungtivitis dan Katarak) $=(0,6154 ; 0,2143)=0,6154$

Maka hasil diagnosa yang didapat atas kasus tersebut, bahwa pasien kemungkinan besar menderita penyakit mata dengan jenis penyakit Konjungtivitis dengan tingkat probabilitas terhadap penyakit tersebut adalah 0,6154 atau $61,54 \%$

\subsection{Analisis Perhitungan Metode Naïve Bayes}

Naïve Bayes Classifier ataupun selalu diucap Bayesian Classification merupakan prosedur pengklasifikasian statistik yang bisa digunakan untuk $r$ (2) :diksi probabilitas keanggotaan sesuatu class [8]. Naive Bayes Classifier merupakan suat. .......da klasifikasi yang berdasar pada teorema Bayes. Metode pengklasifikasian ini memakai metode probabilitas serta statistik yang pertama kali dikemukakan oleh ilmuwan Inggris bernama Thomas Bayes, yakni sesuatu metode untuk memprediksi kesempatan di masa depan bersumber pada pengalaman di masa sebelumnya, sehingga metode ini diketahui sebagai Teorema Bayes [9].

$$
P(C \mid X)=\frac{P(x \mid c) P(c)}{P(x)}
$$

Seorang pasien menderita gejala-gejala : iritasi, pandangan kabur dan mata terasa nyeri

1. Menelusuri runut maju terhadap rule-rule yang ada

Rule 1: IF iritasi = Yes $A N D$ pandangan kabur $=$ Yes $A N D$ mata terasa nyeri $=$ Yes $T H E N$ Penyakit $=$ Konjungtivitis.

Rule 2 : IF pandangan kabur = Yes THEN Penyakit = Katarak.

Berdasarkan hasil dari proses penelusuran dengan menggunakan Teknik infersi Forward Chaining, diketahui bahwa pasien tersebut menderita penyakit mata : Konjungtivitis dan Katarak.

2. Melakukan proses perhitungan dengan metode Nä̈ve Bayes sesuai dengan persamaan rumus (2-2) dan identifikasi nilai kepastian gejala didapat dari tabel 1:

a. Jenis penyakit Konjungtivitis :

Iritasi, pandangan kabur dan mata terasa nyeri

$(\mathrm{P} \mid \mathrm{H} 1)=0,6 / 1,6=0,375$

$(\mathrm{P} \mid \mathrm{H} 2)=0,4 / 1,6=0,25$

$(\mathrm{PlH} 3)=0,6 / 1,6=0,375$

$\mathrm{P}(\mathrm{E} H \mathrm{Hk}) \times \mathrm{P}(\mathrm{Hk})=\left(0,6^{*} 0,375\right)+(0,4 * 0,25)+(0,6 * 0,375)=0,55$

$\mathrm{P}(\mathrm{H} 1 \mathrm{IE})=\left(0,6^{*} 0,375\right) / 0,55=0,409$

$\mathrm{P}(\mathrm{H} 2 \mid \mathrm{E})=(0,4 * 0,25) / 0,55=0,1818$ 
$\mathrm{P}(\mathrm{H} 3 \mid \mathrm{E})=\left(0,6^{*} 0,375\right) / 0,55=0,409$

$\sum$ Bayes $=(0,6 * 0,409)+(0,4 * 0,1818)+(0,6 * 0,409)=0,5635$ (Hasil Bayes)

Maka hasil dari perhitungan dengan metode Nä̈ve Bayes untuk penyakit Konjungtivitis adalah 0,5635 atau $56,35 \%$

b. Jenis penyakit Katarak:

Pandangan kabur

$(\mathrm{P} \mid \mathrm{H} 1)=0,6 / 0,6=1$

$\mathrm{P}(\mathrm{H} 1 \mid \mathrm{E})=\left(0,6^{*} 1\right) / 1=0,6$

$\sum$ Bayes $=\left(0,6^{*} 0,6\right)=0,36$ (Hasil Bayes)

Maka hasil dari perhitungan dengan metode Nä̈ve Bayes untuk penyakit Katarak adalah 0,36 atau $36 \%$

3. Kesimpulan Perhitungan

Nilai Max (Konjungtivitis dan Katarak $)=(0,5635 ; 0,36)=0,5635$

Maka hasil diagnosa yang didapat atas kasus tersebut, bahwa pasien kemungkinan besar menderita penyakit mata dengan jenis penyakit Konjungtivitis dengan tingkat probabilitas terhadap penyakit tersebut adalah 0,5635 atau $56,35 \%$

\subsection{Analisis Perhitungan Metode Certainty Factor}

Certainty Factor merupakan salah satu teori yang bisa digunakan untuk menuntaskan permasalahan ketidakpastian. Certainty Factor alias CF ialah nilai untuk mengukur keyakinan pakar [10]. Metode Certainty Factor( CF) ini diseleksi ketika dalam menghadapi sesuatu permasalahan, kerap ditemui jawaban yang tidak mempunyai kepastian penuh. Untuk mengakomodasi perihal ini sehingga digunakan Certainty Factor( $\mathrm{CF}$ ) guna menggambarkan tingkatan keyakinan pakar terhadap permasalahan yang sedang dialami [11].

$$
\mathrm{CF}\left(\mathrm{CF}_{1}, \mathrm{CF}_{2}\right)=\mathrm{CF}_{1}+\mathrm{CF}_{2}\left(1-\mathrm{CF}_{1}\right) \quad \text { Jika } \mathrm{CF}_{1} \text { dan } \mathrm{CF}_{2}>0
$$

Seorang pasien menderita gejala-gejala : iritasi, pandangan kabur dan mata terasa nyerı

1. Menelusuri runut maju terhadap rule-rule yang ada

Rule 1: $I F$ iritasi $=$ Yes $A N D$ pandangan kabur $=$ Yes $A N D$ mata terasa nyeri $=$ Yes $T H E N$ Penyakit $=$ Konjungtivitis.

Rule 2:IF pandangan kabur $=$ Yes THEN Penyakit $=$ Katarak.

Berdasarkan hasil dari proses penelusuran dengan menggunakan Teknik infersi Forward Chaining, diketahui bahwa pasien tersebut menderita penyakit mata : Konjungtivitis dan Katarak.

2. Melakukan proses perhitungan dengan metode Certainty Factor sesuai dengan persamaan rumus (2-3) dan identifikasi nilai kepastian gejala didapat dari tabel 1 :

a. Jenis penyakit Konjungtivitis :

Iritasi dan pandangan kabur $=0,6+0,4(1-0,6)=0.76(\mathrm{CF}$ kom $)$

$\mathrm{CF}$ kom dan mata terasa nyeri $=0,76+0,6(1-0,76)=0.904($ Hasil $\mathrm{CF})$

Maka hasil dari perhitungan dengan metode Certainty Factor untuk penyakit

Konjungtivitis adalah 0,904 atau 90,4\%.

b. Jenis penyakit Katarak:

Pandangan kabur $=0,6+0(1-0,6)=0,6($ Hasil CF $)$

Maka hasul dari perhitungan dengan metode Certainty Factor untuk penyakit Katarak adalah 0,6 atau $60 \%$

3. Kesimpulan Perhitungan

Nilai Max (Konjungtivitis dan Katarak) $=(0,904 ; 0,6)=0,904$

Maka hasil diagnosa yang didapat atas kasus tersebut, bahwa pasien kemungkinan besar menderita penyakit mata dengan jenis penyakit Konjungtivitis dengan tingkat probabilitas terhadap penyakit tersebut adalah 0,904 atau $90,4 \%$ 


\subsection{Perancangan Sistem}

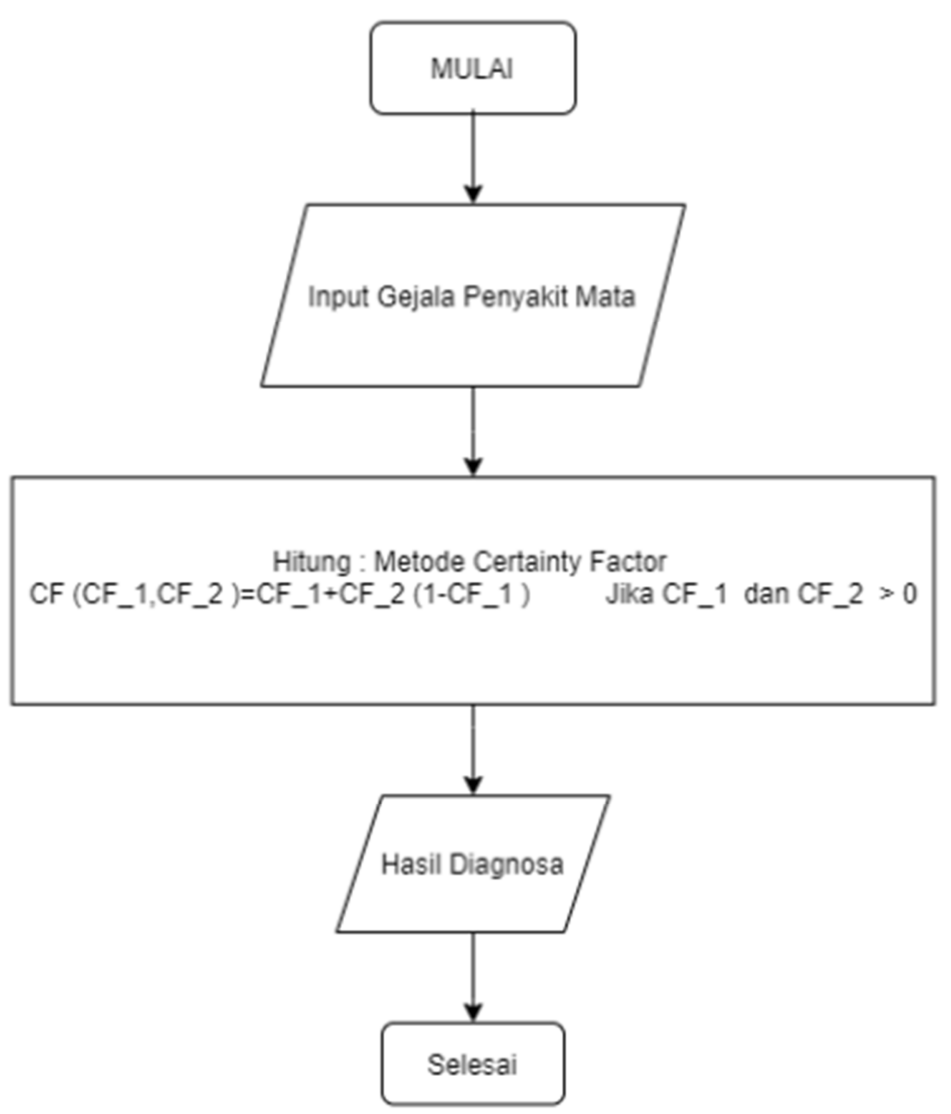

Gambar 1. Flowchar Metode Certainty Factor

Pada gambar 1 dapat dilihat flowchart metode Certainty Factor, penjelasan singkat nya adalah alur proses yang dilakukan ketika user yang akan melakukan konsultasi. Pertama user akan memilih gejala yang dialami nya kemudian akan dihitung atau dikalkulasi menggunakan metode Certainty Factor. 


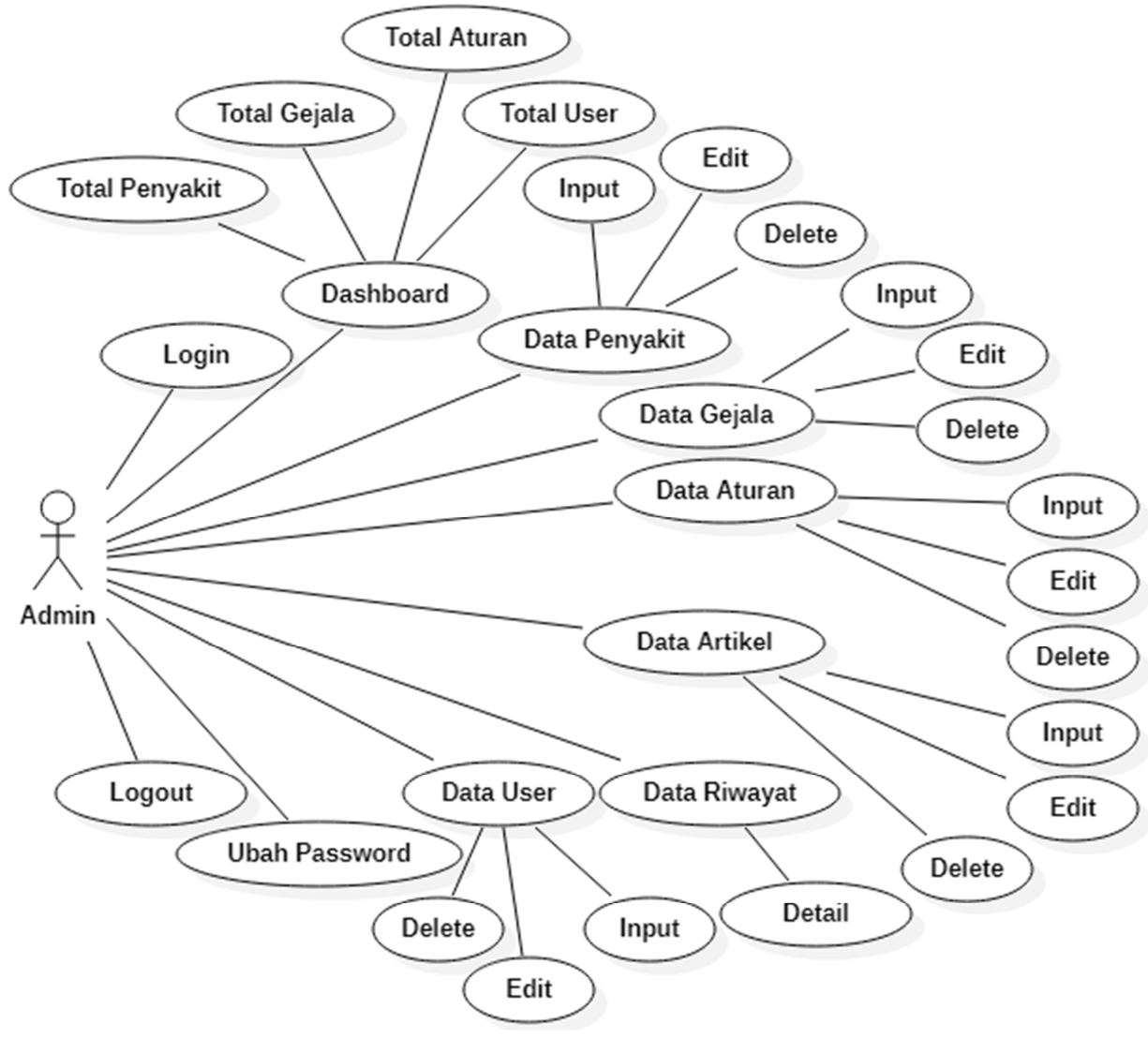

Gambar 2. Diagram Use Case Admin

Pada gambar 2 merupakan diagram use case admin menujunkan bahwa admin merupakan pengguna yang mempunyai wewenang untuk melakukan pemeliharaan sistem dan penambahan data di dalam sistem.

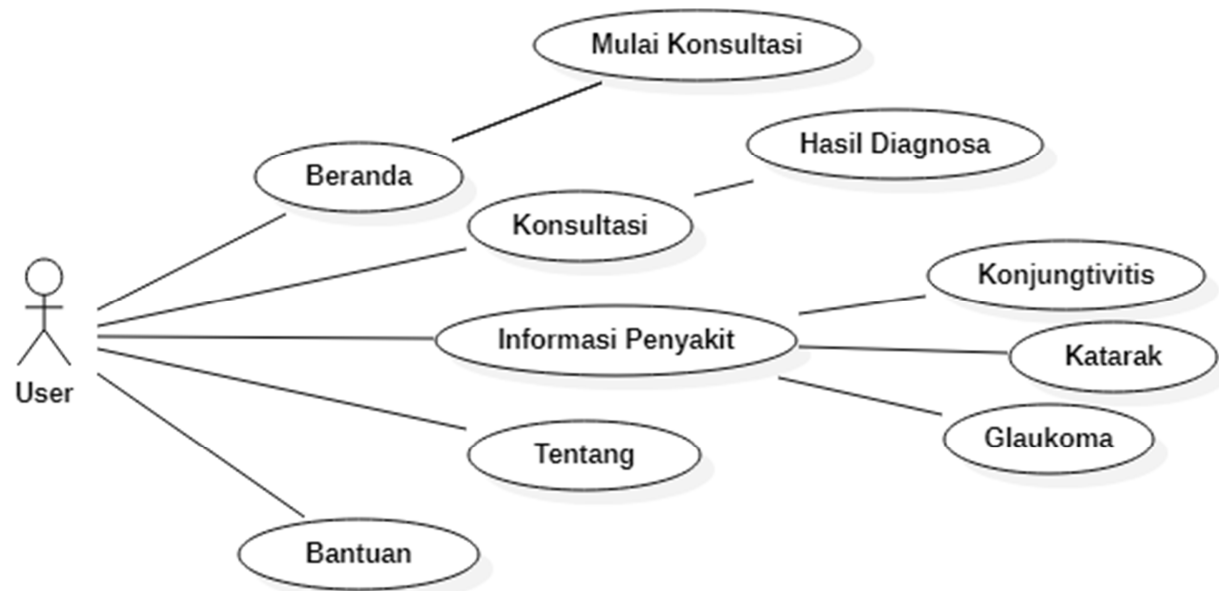

Gambar 3. Diagram Use Case User

Pada gambar 3 adalah pengguna umum atau user, user ini hanya mempunyai hak di dalam sistem untuk melakukan konsultasi gejala penyakit dan melihat data penyakit. 


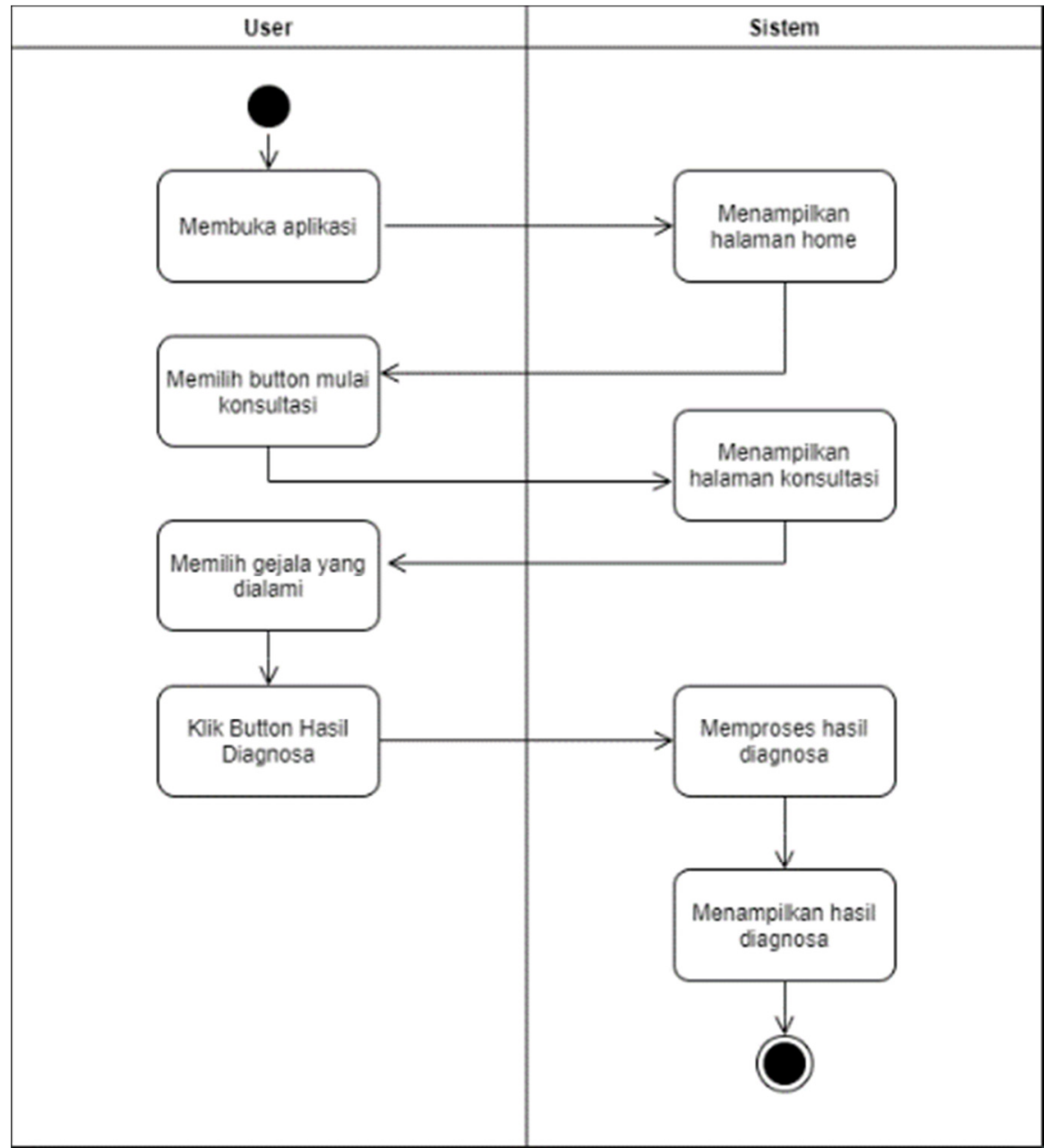

Gambar 4. Diagram Activity Menu User

Gambar 4 merupakan alur proses user yang akan melakukan konsultasi penyakit yang diderita sampai mendapatkan hasil diagnose yang sudah diproses oleh sistem.

\section{HASIL DAN PEMBAHASAN}

\subsection{Hasil Perbandingan Metode}

Tabel 2. Hasil Perhitungan 3 Metode

\begin{tabular}{|c|l|c|c|}
\hline \multirow{2}{*}{ No } & \multicolumn{2}{|c|}{ Metode } & \multicolumn{2}{|c|}{ Jenis Penyakit } \\
\cline { 3 - 4 } & & Konjungtivitis & Katarak \\
\hline 1 & Metode Case Base Reasoning & 0,6154 & 0,2143 \\
\hline 2 & Metode Naïve Bayes & 0,5635 & 0,36 \\
\hline 3 & Metode Certainty Factor & 0.904 & 0,6 \\
\hline
\end{tabular}

Pada tabel 2 kita dapat menyimpulkan bahwa, setelah melaksanakan perhitungan dengan menggunakan metode Case Based Reasoning, Naïve Bayes serta Certainty Factor, sehingga proses berikutnya yaitu memutuskan metode yang paling tepat serta baik untuk menerapkan 
pendiagnosaan penyakit Mata pada manusia. Berdasarakan hasil dari perhitungan ketiga metode tersebut, sehingga diperoleh kesimpulan sebagai berikut:

1. Pada perhitungan dengan metode Case Based Reasoning penyakit yang terpilih merupakan Konjungtivitis dengan nilai probabilitas 0, 6154, sedangkan untuk metode Naïve Bayes memperoleh nilai probabilitas 0,5635 untuk penyakit Konjungtivitis dan metode Certainty Factor menyimpulkan bahwa penyakit yang terpilih yaitu Konjungtivtis dengan nilai probabilitas 0,904. Dari hasil tersebut maka metode Certainty Factor ialah metode yang sangat tinggi atau terbaik yang miliki nilai probabilitas yang paling tertinggi dari ketiga metode tersebut dan ini sudah sesuai dengan diagnose dokter.

2. Dari hasil perhitungan dari metode Case Based Reasoning, Naïve Bayes serta Certainty Factor ketiganya memilih penyakit Konjungtivitis sebab mempunyai nilai probabilitas paling tinggi.

3. Dengan hasil perhitungan diatas, bisa disimpulkan maka untuk mendiagnosa penyakit mata pada manusia, tata cara yang sangat tepat serta terbaik merupakan metode Certainty Factor. Perihal ini cocok dengan ilmu kepakaran jika satu penyakit tidak bisa ditetapkan cuma dengan satu indikasi ataupun dengan kata lain nilai probabilitas nya rendah serta semakin banyak tanda- tanda yang dialami hingga semakin mungkin terdiagnosa kategori penyakit tersebut dengan nilai probabilitas yang tinggi.

\subsection{Pengujian Diagnosa Di Aplikasi}

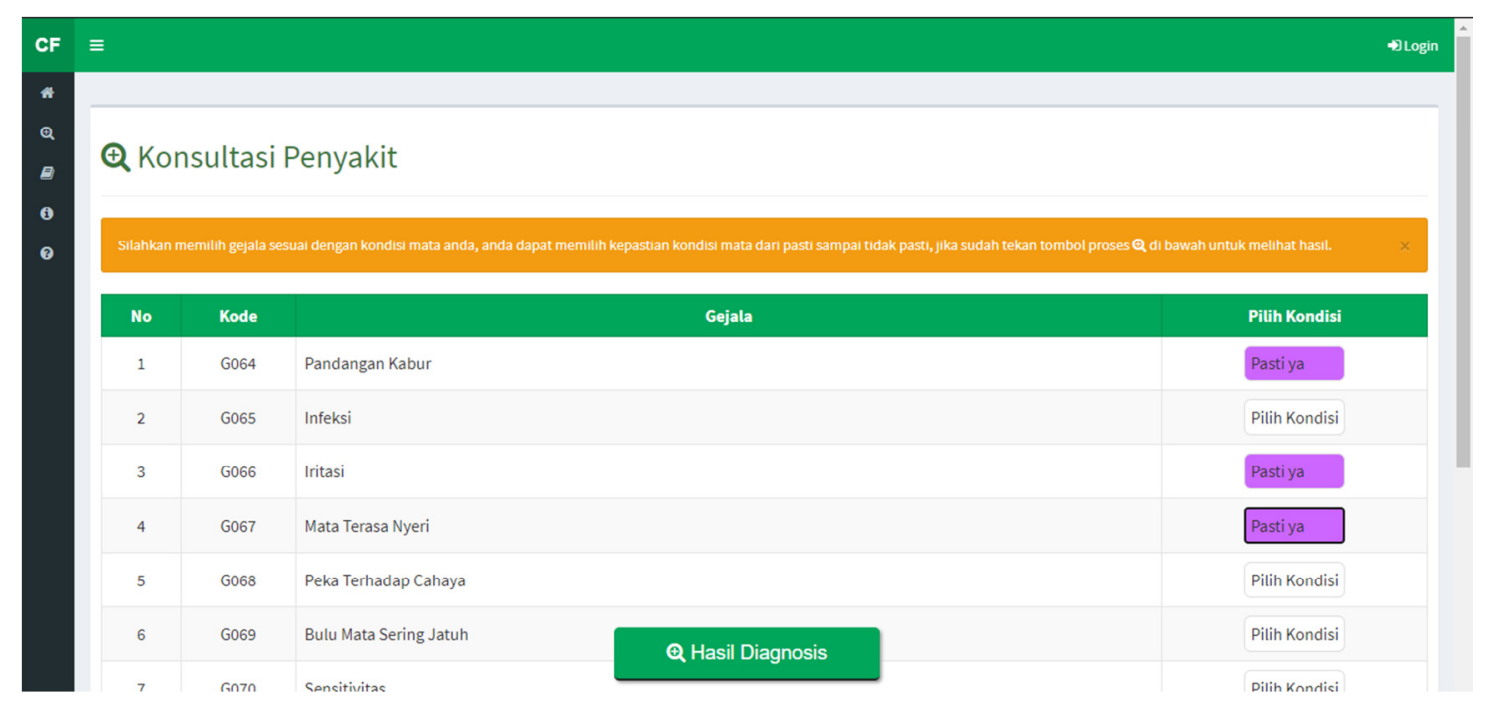

Gambar 6. Halaman Konsultasi Penyakit

Pada Gambar 6 merupakan pemilihan gejala yang sesuai dengan gejala yang diuji untuk mendiagnosa penyakit mata apa dan berapa persentase yang didapatkan apakah sesuai dengan perhitungan manual atau tidak. 


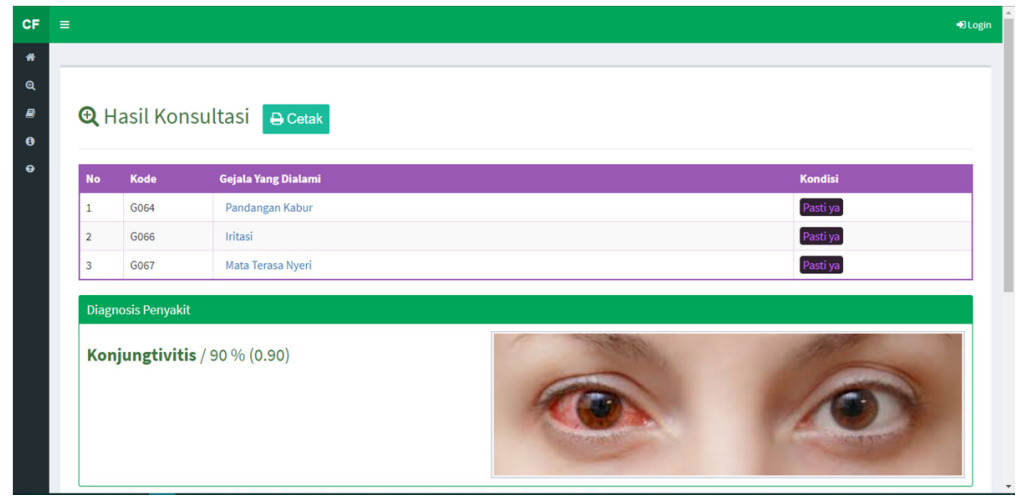

Gambar 7. Halaman Hasil Konsultasi

Pada gambar 7 menjelaskan tentang hasil setelah pengguna menekan button hasil diagnose. Bisa dilihat untuk hasil persentase nya sesuai dengan perhitungan manual yang sudah di uji yaitu $90 \%$.

Jadi kesimpulannya, bahwa hasil perhitungan dengan metode Certainty Factor memiliki tingkat kepastian diagnose mendekati $90 \%$ pada penyakit Konjungtivitis dan ini sudah sesuai dengan diagnose pakar.

\section{KESIMPULAN}

Berdasarkan pada hasil ulasan tentang penerapan analisis perbandingan metode Case Base Reasoning, Naïve Bayes serta Certainty Factor yang sudah dikemukakan, hingga bisa diperoleh beberapa kesimpulan, sebagai berikut:

1. Bersumber pada hasil perhitungan yang sudah dicoba maka bisa diketahui bahwa metode Certainty Factor merupakan metode yang nilai probabilitas paling tinggi dibanding dengan metode Case Based Reasoning serta metode Naïve Bayes.

2. Dengan hasil perhitungan ini maka nantinya implementasi sistem pakar untuk mendiagnosa penyakit mata pada manusia yaitu dengan memakai metode Certainty Factor.

3. Dengan adanya sistem pakar ini, pengguna dapat mudah mengetahui penyakit mata apa yang dialami dan pengguna dapat langsung mendiagnosa diri nya sendiri dengan sistem pakar ini.

\section{DAFTAR PUSTAKA}

[1] S. Yoga, 2019, "Perubahan Sosial Budaya Masyarakat Indonesia dan Perkembangan Teknologi Komunikasi," J. Al-Bayan, Vol. 24, No. 1, pp. 29-46, doi: 10.22373/albayan.v24i1.3175.

[2] W. Purba, S. Aisyah, and S. P. Tamba, 2017. "Perancangan Sistem Pakar Diagnosa Penyakit Mata Katarak Menggunakan Konsep Metode Runut Mundur," JUSIKOM PRIMA (Junal Sist. Inf. Ilmu Komput. Prima), Vol. 1, No. 1,

[3] E. Ongko, "Perancangan Sistem Pakar Diagnosa Penyakit pada Balita," J. Time, Vol. II, No. 1, pp. 1-5, 2014, doi: 10.1007/s13398-014-0173-7.2. 
[4] Yenita Wijaya, 2016. "Sistem Pakar Kerusakan Hardware Komputer Dengan Metode Forward Chaining," J. Momentum, Vol. 18, No. 2, pp. 53-59,

[5] P. S. Ramadhan, 2018, "Sistem Pakar Pendiagnosaan Dermatitis Imun Menggunakan Teorema Bayes," InfoTekJar (Jurnal Nas. Inform. dan Teknol. Jaringan), Vol. 3, Vo. 1, pp. 43-48, doi: 10.30743/infotekjar.v3i1.643.

[6] T. Rismawan and S. Hartati, 2013, "Case-Based Reasoning Untuk Diagnosa Penyakit THT (Telinga Hidung dan Tenggorokan)," IJCCS (Indonesian J. Comput. Cybern. Syst., Vol. 7, No. 1, pp. 67-78, doi: 10.22146/ijccs.2154.

[7] D. Y. Prasetyo, B. Rianto, M. S. Rais, and N. Suwanti, 2021, "Diagnosa Dini Penyakit Mata Menerapkan Metode Case Based Reasoning (CBR)," Vol. 5, No. April, pp. 360-369, doi: $10.30865 / \mathrm{mib} . v 5 \mathrm{i} 2.2779$.

[8] W. B. Zulfikar and N. Lukman, 2016, "Perbandingan Naive Bayes Classifier Dengan Nearest Neighbor Untuk Identifikasi Penyakit Mata," J. Online Inform., Vol. 1, No. 2, pp. 82-86, doi: 10.15575/join.v1i2.33.

[9] M. Syukri Mustafa, M. Rizky Ramadhan, and A. P. Thenata, 2017 "Implementasi Data Mining untuk Evaluasi Kinerja Akademik Mahasiswa Menggunakan Algoritma Naive Bayes Classifier," Citec J., Vol. 4, No. 2, pp. 151-162,.

[10] H. Fahmi, 2019, "Sistem Pakar Mendiagnosa Penyakit Mata Katarak Dengan Metode Certainty Factor Berbasis Web," Matics, Vol. 11, No. 1, p. 27, doi: 10.18860/mat.v11i1.7673.

[11] P. S. Ramadhan and U. F. S. Pane, 2018, "Analisis Perbandingan Metode (Certainty Factor, Dempster Shafer dan Teorema Bayes) untuk Mendiagnosa Penyakit Inflamasi Dermatitis Imun pada Anak," J. SAINTIKOM (Jurnal Sains Manaj. Inform. dan Komputer), Vol. 17, No. 2, pp. 151-157, [Online]. Available: https://ojs.trigunadharma.ac.id/index.php/jis/article/view/38. 